\title{
Various ICT-based applications and their uses to support smart city implementation in the Regency of Blora
}

\author{
Rini Rachmawati*, Pinta Rachmadani, Vivy Nur Anifa, and Fina Lutfiana \\ Department of Development Geography, Faculty of Geography, Universitas Gadjah Mada, Yogyakarta, Indonesia
}

\begin{abstract}
One of the implementations of the smart city concept is by making use of Information and Communication Technology (ICT)-based applications in providing public services. The Regency of Blora is one of the Indonesian regencies belonging to the 100-Smart-City. The aims of the research are identifying the applications contained in the programs in the smart city master plan on each dimension, identifying the applications most used to support smart city implementation, analyzing The Use of Aplication, and recommending applications required for implementing smart city. This research uses a qualitative approach. This research includes an application-based Blora Smart City development program implemented in six smart city dimensions. Applications that have been used properly are selected through focus group discussions (FGD). Application provider informants were selected purposively, while for application users five informants were selected. Data processing was carried out using in-depth interview transcripts. Data analysis was carried out by descriptive qualitative. The research result show that various applications have been used to support the realization of the Regency of Blora as a smart city. Some of the society members have been making use of the applications to deserve public services. However, to support the uses of ICTbased applications in an optimum level, it is necessary to make it easy to access internet, to socialize the existence of applications, and to obtain aspiration from local people for the policy of applying the applications. Evaluation of application utilization is recommended as a follow-up research through structured interview surveys of application users with a larger number of respondents.
\end{abstract}

\section{Introduction}

A city that applies the policy of smart city is certainly different from that in general. Smart city policy has a positive impact that cannot be ignored in urban innovation as measured by the number of patents from four alternative technology classes, namely total patent applications, high technology patent applications, ICT patent applications, and smart city patent applications [1]. Regarding the application for example in the form of timely reports of information to the police, hospitals and emergency services, implementation of protective measures to ensure the safety of older adults and school children, and the design of policies to ensure more road safety [2]. Such applications are certainly very useful for the public.

The planning to develop a region that is based on the concept of smart city has become a strategy to realize a smart city. The strategy is by applying ICT in the resource management in order to provide more effective and efficient services for the people. The 100-smart-city movement is one of the programs initiated by the Ministry of Communication and Information, the Ministry of Home Affairs, the Ministry of Public Works and Public Housing, Board for National Development Planning, and Presidency Staff to make smart cities come true. One of the regencies in the Indonesian 100smart-city movement is the regency of Blora, Central Java Province. By applying the concept of smart city, it is expected that every city/regency is able to make use of ICT for improving its public services.

The implementation of smart city in the Regency of Blora has been well planned. There is a master plan document of Blora Smart City in which several planned programs to implement are found. The programs cover six dimensions of smart city development, namely smart governance, smart society, smart economy, smart living, smart branding, and smart environment. One of the program implementations is by applying ICT-based applications.

ICT becomes the basis for developing smart city. Smart city becomes one of the concepts in integration between planning and managing of city [3]. This is important to create an intelligent, educated, and highly valued morality so that a better and more sustainable quality of life can be obtained [3]. Various innovations using ICT are applied as a form of application support for smart city implementation. Technology is not only used to implement smart city, but it also deals with how society play an important role in it. The main point in supporting the establishment of smart city is good integration among the systems/applications, infrastructure, and human resource [4]. This is very important to establish sustainable living [4]. By making use of ICT-based applications, it is expected that public services from the government can be realized in a more effective and efficient way.

\footnotetext{
* Corresponding author: rinirachma@ugm.ac.id
} 
Smartphone-based application or popularly called mobile application is one the means to support smart city. The means that is considered interactive enough is the application on cellular phone because it is in line with the ICT improvement and activities of people who have been used to using cellular phone. Various features found on the application enable information to be available in an easy and accurate way and they can save files safely. The data that are integrated to one another make the users easy to search and process them [5]. In adopting cloud computing it is necessary to pay attention to the level of data protection and privacy, confidentiality, and security required. This is related to public administration will store citizen data in the cloud [6]. However, this paper will not be discussed further related to cloud computing because the research conducted is more focused on the variety of applications and their utilization.

In order that users can access services provided by a smart city, the realization of smart city needs components activated with Internet of things (IoT). Smart city involves many actors, including government and community participation that adjusts to the needs of the region and the people in the area. One of the advantages of smart city is certainly aimed at increasing the welfare of society [7]. This can be in the forms of accessing public services easily, reducing environmental pollution, integrating system and services as well as developing a city sustainably [7]. Smart city is an approach in solving city problems by maximizing technology. The creation of smart cities is based on relevant concepts, such as IoT (Internet of Things), Cyber-Physical-Systems (CPS), and cellular computing technology to improve well-being [8]. However, the implementation of the use of the system certainly has many challenges, such as interoperability of different technologies [8]. This paper will not discuss in detail the use of the system.

Several researchers from universities, industries, businesses, and government institutions are currently exploring technology from three main perspectives, i.e. scientific theory, theoretical design, and user's experience [9]. This is very useful to empower the users by giving them education related to how to understand and control their environment through new knowledge that can be accessed interactively, commonly regarded as an application that is not traditional anymore [9]. For this reason, a study related to the perspective of users of public services and the use of applications is important.

To find out about the application supporting the implementation of smart city and its utilization and the need for application development through the recommendations that can be given, this research was carried out with the aim of;

The aims of the research are; 1) Identifying the applications contained in the programs in the smart city master plan on each dimension, 2) Identifying the applications most used to support smart city implementation, 3) Analyzing The Use of Aplication, 4) Recommending applications required for implementing smart city.

\section{Materials and Methods}

This research applies a qualitative approach. This research includes an application-based Blora Smart City development program that has been implemented in six dimensions of smart city. From the 6 dimensions of smart city, applications that have been used properly are selected. Determination of whether the application has been used properly or not, is obtained from the results of focus group discussions of each smart city dimension group in the smart city evaluation forum activity. Then proceed with a field survey conducted in-depth interviews with application providers and application users. Application provider informants are selected purposively, namely relevant officers to provide information. Meanwhile, five informants were selected for each application. The selection of five informants using the application is intended to cross check the answers between the informants. Likewise, the answers between application providers and application users are intended as enrichment of information about the application. Thus the triangulation is fulfilled and the reliability and validity of the data can also be fulfilled.

The processing of qualitative data is made by using the transcript of in-depth interview. The data are then processed, from doing the datum reduction to presenting the data in order that they are easy to comprehend. To analyze the data, what is done is a descriptive qualitative way and the data are presented in the form of descriptions.

\section{Results and discussions}

Smart city is defined as a concept based on information and communication technology. In its application, it also has something to do with both physical and non-physical aspects in developing smart infrastructure. Therefore, the implementation of smart city should be done by applying a holistic approach, meaning that all factors in smart city need to be calculated thoroughly since they are related to one another [10]. Indonesia has implemented the concept of smart city in many cities or regencies, one of which is the Regency of Blora, Central Java.

The Vision Mission of the Middle-term Development Plan of the Regency of Blora Years 2016 - 2021 says "the accomplishment of Blora as a smart city focusing on the development of agroindustry and agroforestry toward wealthy society with high human values. There are six dimensions to make Blora as a smart city come true, namely smart governance, smart branding, smart economy, smart living, smart society, and smart environment. To do so, it should be in line with the development vision; this is by, among others, providing more effective and efficient public services. One of the steps to realize more effective and efficient public services is by using ICT-based applications.

On each dimension of smart city, there are several programs that are based on an application implemented to support public services to be better. In the dimension of smart governance of the Regency of Blora, there are several applications that function to make it easy for permit process and to audit the performance of ASN 
(Aparatur Sipil Negara/civil servants). The applications that function for making permit process easy to deal with are Si Cantik, E-Kios, E-Samin, and PAKREBO. Meanwhile, the applications that function to help audit the performance of ASN are E-Skp, Lapor Bos, and SIMPEG.

The dimension of smart branding has several program plans based on an application, such as information system for tourism and GIS-based investment map. The two applications will be under the management of the Agency for Youth, Sports, Culture, and Tourism to support the tourism branding of the Regency of Blora. In addition to the two applications, there are also other applications on the dimension of smart branding, namely e-farming by the Agency for Agriculture and Food Tenacity and petunjuk arah digital (digital direction) by the Agency for Housing, Settlement, and Transportation.

In relation to the dimension of smart economy in the Regency of Blora, the applications are e-retribution and Blora e-commerce. The e-retribution application has been implemented in every market in the regency of Blora. Meanwhile, the Blora e-commerce application is planned to be managed by the Agency for Communication and Informatics as a means to market the products of local entrepreneurs.

On the application of the dimension of smart society, there is a means for receiving the people's complaints sent online. Meanwhile, to provide integrated services in case of emergency, the application PC 119 is available for society to use. That application will be managed by the Agency for Communication and Informatics, Pamong Praja Police, Agency for Health and Board for Regional Disaster Tackling. The application on the dimension of smart society is useful for society to make complaints about emergency condition to the respective agency.

On the dimension of smart living, there are several applications that will be managed by the Regional Hospital of Blora and the Agency for Health to support health services. They are, among others, SIM RS, Sedot A Mas, simpus, SPDGT, and SMS Gateaway. All those applications are meant to enable society to both obtain information and get health services in an easy way. The information and health services can be about the availability of beds for in-patients, on-line admission, etc. On the hand, the hospital can also receive feedback from SIM RS application users so that the hospital can improve itself for better services[4]. For those who do not have a cellular phone so that they cannot download the application, the Regional Hospital also provides SMS service[4]. That way, this method is expected to enable society to access information easily [4].

The applications on the dimension of smart environment are, among others, SIMAS LH Online and AQMS (Air Quality Monitoring System). These two applications will be managed by the Agency for Living Environment. They are expected to be able to give services and provide official information on environmental issues to society.

The results of the focus group discussion on each smart city dimension held in the smart city evaluation activities show that among all the applications for public services, there are three applications that have been operating and used by the community, namely Sedot A Mas, E-retribution, and PSC 119. For this reason, data collection is carried out through in-depth interviews with the providers and users of the applications in the three applications. The number of informants for each application is five people in each application.

Sedot A Mas is an application for On-line Admission System, information on bed availability in the Regional Hospital, and complaints from society. It is an application for public services, mainly for society to get health services. One of the health facilities that have been using this application is Regional Public Hospital of the Regency of Blora. The local people who want to have their health checked treated at the respective hospital may use this application for on-line admission. In addition, they may also get information on the bed availability for in-patients. Sedot A Mas application are presented on Figure 1.

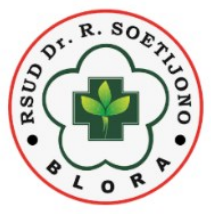

\section{Sedot A Mas RSUD dr. R. Soetijono} Blora

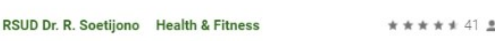

$3+$

This app is compatitle with your device.

田 Add to Wishlist
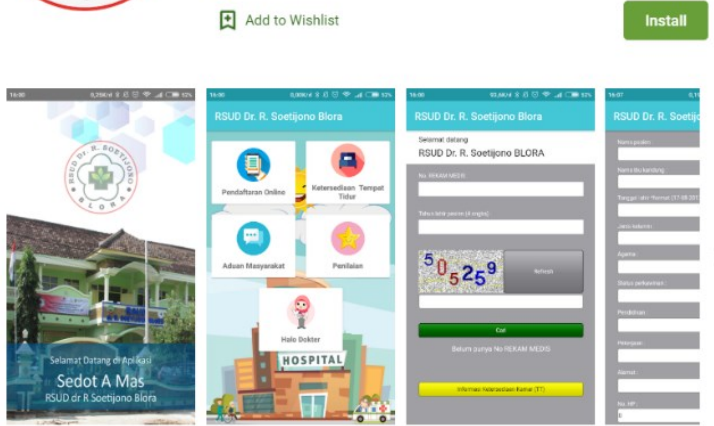

Fig. 1. Sedot A Mas Application

(Sources:https://play.google.com/store/apps/details?id=id.go. blorakab.rsudblora.rsuddrrsoetijonoblora\&hl=en_US, accessed April 18, 2020)

The results of in-depth interviews with application providers and application users are as shown in Tables 1 and 2.

Table 1. Provision of Supporting Applications for the Implementation of Smart City in Blora Regency

\begin{tabular}{|l|l|l|}
\hline Application & informant & Information \\
\hline $\begin{array}{l}\text { Sedot A Mas } \\
\text { application } \\
\text { Blora }\end{array}$ & $\begin{array}{l}\text { Updating data is one of the } \\
\text { obstacles in using the Sedot } \\
\text { A Mas application at the } \\
\text { Blora Hospital }\end{array}$ \\
\hline application & $\begin{array}{l}\text { Officer at the } \\
\text { Agency for Trade, } \\
\text { Cooperatives, and } \\
\text { Small and Middle } \\
\text { Enterprises, }\end{array}$ & $\begin{array}{l}\text { The e-retribution application } \\
\text { has an impact on increasing } \\
\text { public trust in officers }\end{array}$ \\
\cline { 2 - 3 } & $\begin{array}{l}\text { Officer from the } \\
\text { Agency for Trade, } \\
\text { Cooperatives, } \\
\text { Small and Middle } \\
\text { Enterprises }\end{array}$ & $\begin{array}{l}\text { Internet signal is one of the } \\
\text { obstacles in using the e- } \\
\text { retribution application }\end{array}$ \\
\hline $\begin{array}{l}\text { PSC 119 } \\
\text { application }\end{array}$ & $\begin{array}{l}\text { an officer at PSC } \\
\text { B19 }\end{array}$ & $\begin{array}{l}\text { Socialization regarding the } \\
\text { PSC 119 application is still } \\
\text { lacking }\end{array}$ \\
\hline
\end{tabular}

Source: In-depth interview 2020 
Table 2. Utilization of Supporting Applications for the Implementation of Smart City in Blora Regency

\begin{tabular}{|c|c|c|}
\hline Aplikasi & Informan & Informasi \\
\hline \multirow[t]{5}{*}{$\begin{array}{l}\text { Sedot A Mas } \\
\text { application }\end{array}$} & $\begin{array}{l}\text { Patient1 at RSUD } \\
\text { Blora }\end{array}$ & \multirow{5}{*}{$\begin{array}{l}\text { The benefits of the Sedot A } \\
\text { Mas application have been } \\
\text { felt by users (patients) }\end{array}$} \\
\hline & $\begin{array}{l}\text { Patient2 at the } \\
\text { RSUD Blora }\end{array}$ & \\
\hline & $\begin{array}{l}\text { Patient3 at the } \\
\text { RSUD Blora }\end{array}$ & \\
\hline & $\begin{array}{l}\text { Patient } 4 \text { at the } \\
\text { RSUD Blora }\end{array}$ & \\
\hline & $\begin{array}{l}\text { Patient5 at the } \\
\text { RSUD Blora }\end{array}$ & \\
\hline \multirow[t]{5}{*}{$\begin{array}{l}\text { E-retribution } \\
\text { application }\end{array}$} & $\begin{array}{l}\text { Merchant1 at the } \\
\text { Blora Public } \\
\text { Market }\end{array}$ & $\begin{array}{l}\text { Income from non- } \\
\text { permanent merchants is an } \\
\text { obstacle to implement a } \\
\text { payment system using e- } \\
\text { retribution }\end{array}$ \\
\hline & $\begin{array}{l}\text { Merchant2 at the } \\
\text { Blora Public } \\
\text { Market }\end{array}$ & $\begin{array}{l}\text { One of the merchants has } \\
\text { felt the benefits of using e- } \\
\text { retribution }\end{array}$ \\
\hline & $\begin{array}{l}\text { Merchant3 at the } \\
\text { Blora Public } \\
\text { Market }\end{array}$ & $\begin{array}{l}\text { There are still traders who } \\
\text { prefer manual payment } \\
\text { methods }\end{array}$ \\
\hline & $\begin{array}{l}\text { Merchant } 4 \text { at the } \\
\text { Blora Public } \\
\text { Market }\end{array}$ & $\begin{array}{l}\text { There are still traders who } \\
\text { have not benefited from e- } \\
\text { retribution }\end{array}$ \\
\hline & $\begin{array}{l}\text { Merchant5 at the } \\
\text { Blora Public } \\
\text { Market }\end{array}$ & $\begin{array}{l}\text { There are still traders who } \\
\text { prefer manual payment } \\
\text { methods }\end{array}$ \\
\hline \multirow[t]{5}{*}{$\begin{array}{l}\text { PSC 119 } \\
\text { application }\end{array}$} & User1 of PSC 119 & $\begin{array}{l}\text { PSC } 119 \text { application users } \\
\text { have benefited from this } \\
\text { application }\end{array}$ \\
\hline & User2 of PSC 119 & $\begin{array}{l}\text { The large amount of } \\
\text { internet data usage when } \\
\text { accessing the PSC } 119 \\
\text { application is one of the } \\
\text { obstacles }\end{array}$ \\
\hline & User3 of PSC 119 & $\begin{array}{l}\text { PSC } 119 \text { application users } \\
\text { have benefited from this } \\
\text { application }\end{array}$ \\
\hline & User4 of PSC 119 & $\begin{array}{l}\text { PSC } 119 \text { application users } \\
\text { have benefited from this } \\
\text { application }\end{array}$ \\
\hline & User5 of PSC 119 & $\begin{array}{l}\text { PSC } 119 \text { application users } \\
\text { hope that the service of } \\
\text { complaints will be further } \\
\text { improved }\end{array}$ \\
\hline
\end{tabular}

Source: In-depth interview 2020

More and more society members have been using the Sedot A Mas Application and they feel the benefits of it since it is of a great help. They find it much easier to make an admission for health service. As a result, the uses of this application can reduce the queue of patients in the hospital. Such a condition is in line with the statement of two patients at the Regional Public Hospital of the Regency of Blora after using the Sedot $A$ Application, quoted as saying:

"This application makes it easy for admission, not taking long time to stand in line" (Informant: patient1 at RSUD Blora, 12 March 2020).

"Really makes it easy, no need to stand in line for admission number at the hospital" (Informant: patient2 at the RSUD Blora, 12 March 2020)

E-retribution is an application used and managed by the Agency for Trade, Cooperatives, Small and Middle Enterprises in the Regency of Blora to collect retribution fee for kios (small shop) rent from the merchants in the markets. One of the markets that have applied the application to collect the rent fee is Sido Malmur Public Market of Blora. The use of this e-retribution application is expected to be able to give benefits, such as increasing trust from the merchants to officers since the payment is not in cash anymore so that the money will go the respective agency directly. One of the officers from the respective agency is quoted as saying:

"Trust to officers increases because they do not receive cash anymore, instead, the money goes to the regional treasury automatically" (Informant: officer at the Agency for Trade, Cooperatives, and Small and Middle Enterprises, 11 March 2020)

The payment method using e-retribution application is done by visiting the merchants one by one once in three days. The retribution payment uses this application is not in cash anymore. Instead, every merchant has a card on which the holder has done the top-up before. The retribution fee that has been paid by a merchant will go to the respective agency directly. The uses of eretribution application are presented on Figure 2.

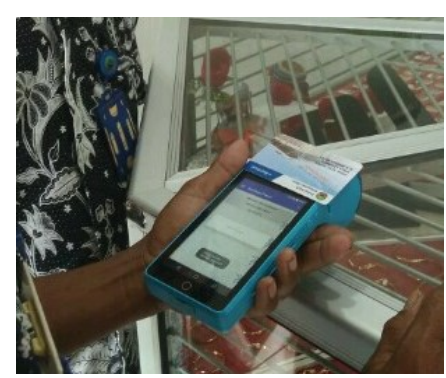

Fig. 2. Uses of E-retribution Application

PSC 119 is an application aimed at providing services for receiving people's complaint in case of emergency condition. The society members are able to report any emergency conditions taking place in their surrounding area, such as an accident, natural disaster, etc. In addition, they are also able to find out information on the availability of blood stock. The complaint that they report must be 'real time' and accompanied with photos and location sent onto the PSC 110 Application. An officer who is in charge of managing the PSC 119 Application will receive the complaint and someone from the respective agency will come to help the complaint or information sender. The uses of PSC 119 Application are presented on Figure 3.

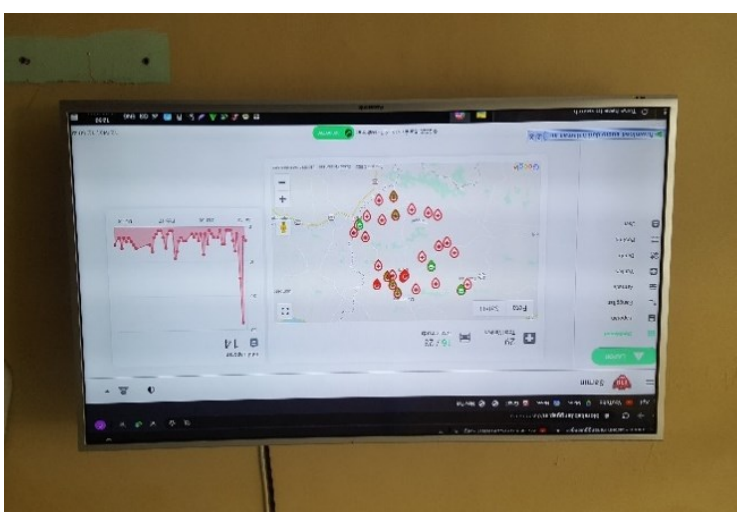

Fig. 3. Uses of PSC 119 Application

The local people have felt the benefits from this PSC 119 Application. Sending information on emergency condition is made easier. Because of this application, an emergency condition or a traffic accident can be tackled 
more quickly. The uses of the PSC 119 Application are in line with those from which they have benefitted, quoted as saying:

"The benefit is that it is much easier to take an evacuation when there is natural disaster or traffic accident" (Informant: user1 of PSC 119, 12 March 2020).

In the implementation stage, there are, in fact, several different obstacles in using the applications for public services in the Regency of Blora. In general, the obstacles are, for example, the availability of basic infrastructure, services on the applications, and the awareness of society as well. The availability of basic infrastructure becomes the main obstacle to make Blora as a smart city come true. The basic infrastructure is, for example, the presence of internet signal or WiFi that does not cover all areas in the respective regency. In relation to the signal obstacle, an officer from the agency related to the E-retribution Application is quoted as saying:

"Sometimes no signal when a merchant wants to pay for retribution fee" (Informant: an officer from the Agency for Trade, Cooperatives, Small and Middle Enterprises, 11 March 2020)

The absence of internet is especially found in villages. Such an obstacle makes those living in villages find trouble using ICT-based applications for public services. Not only those living in villages, those belonging to low-income people also find it trouble accessing information and services using ICT-based application as there is no free Wi-Fi for them. In this case, economical burden is what they face. In relation to the obstacle of internet signal, a user of PSC 119 application is quoted as saying;

"No enough data to access this application since the internet data needed is quite large" (Informant: user2 of PSC 119 application, 12 March 2020)

The service feature on application is also one of the obstacles. It needs to be adapted to the condition of society. This is of primary concern in order that more and more society members can feel the benefits from the applications. The obstacle of service feature that is not adapted to the condition of society is found on the eretribution application. The merchants at the Blora Public Market Sido Makmur do not fully feel the benefits from the e-retribution application. They think that paying for the retribution on cash (off-line) is preferable as they do not make fixed daily income. Efficiency and effectiveness for the process of retribution payment can perhaps be achieved by using an ICT-based application. However, the condition of certain groups of society as user needs to be taken into consideration. Complaints concerning the use of eretribution application is made by one of the merchants at the respective market, quoted as saying:

"When the market is quiet from shoppers, paying for the retribution is impossible. I hope it could get back, like what I did, paying for the retribution daily" (Informant: a merchant at the Blora Public Market, 12 March 2020)

The awareness of the people in the Regency of Blora to use application services also needs to be increased. Some of the society members still prefer to use telephone to make complaints or give information on emergency condition even though PSC 119 application is already available. Socialization concerning the use of the applications needs to be increased in order that they become aware of the presence of ICT-based applications that can make public services much easier to serve. The limited participation from the society in using the PSC 119 application is stated by an officer at the PSC 119, quoted as saying:

"Socialization to society is still limited so there is still a small number of people using services based on application. Instead, they prefer to use telephone" (Informant: an officer at PSC 119, 11 March 2020)

From this study an unexpected picture was obtained that it turned out that the community was not too difficult to use the applications that had been provided. In this case an example is the use of Sedot A Mas, which is seen as making it easier for registration services, and this is done by people who live in rural areas as long as they can still get good internet signals.

However to find out the success or achievement of how each application is used to support the implementation of smart city, it is necessary to make efforts for evaluation. The success of ICT-based applications can be seen from how the society benefit from them. In addition, evaluation can also be used to find out obstacles that have taken place during the operation of ICT-based application for public services. Therefore, by knowing the success made and obstacles faced, this can be used as the basis for planning the development of ICT-based applications in the future.

\section{Conclusion}

The variety of ICT-based applications is quite complete and supports easy access to public services and smart city implementation. The benefits from ICT-based applications in the implementation of smart city in the Regency of Blora have been felt by local society. They think that public services are now more efficient and effective. However, there are still some obstacles faced. They are, for example, availability of main infrastructure such as internet and $\mathrm{WiFi}$, features of application service that do not match the condition of society, and the participation of society in using ICTbased applications.

One of the recommendations that can be given from the results of this study is the need for evaluation to determine the success or achievement of each application used to support the implementation of smart cities. This evaluation-related study can be carried out for the next research agenda by means of a structured interview survey of application users with a greater number of respondents than the number of informants taken in this study.

The author wishes to thank the Faculty of Geography, Universitas Gadjah Mada for the Research Grant in the year 2020. 


\section{References}

[1] A. Caragliu and C. F. D. Bo, "Smart innovative cities: the impact of smart city policies on urban innovation," Technology Forecasting \& Social Change 142, pp. $374-383,2019$.

[2] N. P. Rocha, A. Dias, G. Santinha, M. Rodrigues, A. Queiros, and C. Rodrigues, "Smart cities and public health: a systematic review," International Conference on Health and Social Care Information Systems and Technologies 164, pp. 516 - 523, 2019.

[3] O. K. Sulaiman and A. Hasibuan, "Smart city, konsep kota cerdas sebagai alternatif penyelesaian masalah perkotaan kabupaten/kota, di kota-kota besar provinsi sumatera utara," Buletin Utama Teknik, vol. 14, pp. 127 - 135, 2019.

[4] R. Rachmawati, "ICT-based innovation in the smart city masterplan and its relation to regional planning," the 4th IOP Conf. Series: Earth and Environmental Science 328, pp. 1 - 5, 2019

[5] R. Rachmawati, E. Ramadhan, and A.A. Rohmah, “Aplikasi smart province 'jogja istimewa': penyediaan informasi terintegrasi dan pemanfaatannya," Majalah Geografi Indonesia, vol. 32, pp. $14-23,2018$.
[6] B. D. Martino, G. Cretella, and A. Esposito, "HOLACONF - cloud forward: from distributed to complete computing, towards a legislation-aware cloud computing framework," in Procedia Computer Science '68, 2015, pp 127 - 135.

[7] S. Y. Tan and A. Taeihagh, "Smart city governance in developing countries: a systematic literature review," sustainability, vol. 12, pp. 1-29, 2020.

[8] G. Marques, N. Miranda, A. K. Bhoi, B. G. Zapirain, S. Hamrioui and I. d. 1. T. Díez, "Internet of Things and Enhanced Living Environments: Measuring and Mapping Air Quality Using Cyberphysical Systems and Mobile Computing Technologies," sensors, vol. 20, pp. 1-20, 2020.

[9] K. M. Sadique, R. Rahmani, P. Johannesson, "Towards security on internet of things: applications and challenges in technology," The 9th International Conference on Emerging Ubiquitous Systems and Pervasive Networks 141, pp. 199 - 206, 2018.

[10] A. Hayati, A. S. Utami, K. Bararatin, H. R. Santosa, G. Weichart and M. K. Valent, "Local smart initiatives to enhance sustainable settlement," IOP Conf. Series: Earth and Environmental Science 402, pp. 1-14, 2020. 